\title{
Do Public to Private Buyouts Improve Target's Efficiency?
}

\author{
Miller Lloyd ${ }^{1, *}$, Hawkes Denise ${ }^{2}$ \\ ${ }^{1}$ Department of International Business \& Economics, University of Greenwich, UK \\ ${ }^{2}$ Institute of Education, University College London, UK
}

Copyright $(\subset 2015$ by authors, all rights reserved. Authors agree that this article remains permanently open access under the terms of the Creative Commons Attribution License 4.0 International License

\begin{abstract}
This paper uses a sample of 55 companies involved in UK public to private buyouts (P-T-P) and DEA to investigate efficiency in the UK manufacturing industry during the period 1997-2007. For the sample used and period investigated, no evidence is found that companies involved in public to private buyout ownership changes operate more efficiently than a control sample of PLCs not involved in buyouts. The results suggest that the policy rhetoric that buyouts promote efficiency in public companies in the UK is not supported.
\end{abstract}

Keywords Buyouts, Efficiency, Private Equity, Public to Private Buyouts

\section{Introduction}

For many years, the British Private Equity and Venture Capital Association (BVCA), the trade body of UK private equity firms, have maintained in a string of self-commissioned reports and press releases that companies involved in public to private buyouts (P-T-P) and owned by its members outperform Public Limited Companies (PLCs) on every matrix of efficiency. Such claims are consistent with Williamson (1964) who asserts that "public production is inherently less efficient than private production". This theory has in turn given rise to the agency theory suggestion that managers of PLCs cannot be trusted to operate their companies in the best interest of shareholders (Jensen and Meckling, 1976; Jensen, 1988) as they will place their own interest ahead of their shareholders. Managerial divergence from shareholders interest; it is argued; will lead to poor corporate behavior, and therefore inefficiencies (Manne, 1965; Mead, 1968; Jensen and Meckling, 1976).

In order to incentivise managers to create corporate efficiency, researchers such as Jensen and Murphy (1990) recommend reward compensation schemes that link chief executives officers' compensation to corporate performance. Green (1992), Garvey, (1992), and Kaplan and Stein (1993) all provide empirical evidence to support the agency prediction that aligning managerial interest to that of shareholders will provide positive incentives for managers to look for efficiency gains that will increase the value of the company, and therefore their own stakes in the company. This has given rise to Manne (1965), Mead (1968), and Jensen (1988) disciplinary mergers theory prediction that plants or companies with poor performance will become takeover targets, and will have improved performance after the takeover, and to the market for corporate control hypothesis which states that superior management teams will target underperforming companies in takeover bids. Indeed, the market for corporate control theory defines corporations as an arena in which alternative management teams compete for the right to manage corporate resources, such as employees and free cash flows (Manne, 1965; Jensen and Ruback, 1983; Jensen, 1988; Jarrell et al 1988), and is viewed as a major component of the managerial labour market (Jensen, 1988).

Over the last two decades, private equity firms have played an increasingly important role in radically restructuring organisations worldwide through buyouts (Alexson et al., 2007, Wright et al. 2009). In 2005, the total UK buyout market accounted for over half of all acquisitions by value compared to less than 20 per cent two decades earlier (Wright et al, 2006). Large returns received by corporate shareholders in early buyouts are attributed to improved management and increased efficiency brought about by buyout restructuring (Jensen, 1984, 1988VCA).

Despite the confident claims of the BVCA that its members are able to outperform PLCs on all matrixs of efficiency, it has consistently failed to provide much academic evidence to support its claims of superior efficiency over PLCs. Moreover, as the UK private equity industry grew and the size of private equity funds increased and started to target whole and larger PLCs in public to private (P-T-P) buyout deals, opposition to the industries' activities increased. In the early buyout phase, DeAngelio (1986) warned that buyouts engendered potentially severe conflicts of interest for insider managers, who both have a 
fiduciary duty to negotiate a fair value for their publicly held shares and are themselves the purchasers of these shares. Similarly, Lowenstein (1986); Law (1986); Drucker (1986, 1988); Shleifer and Summers (1988) argue that buyouts are little more than means of capturing rents, and create little or no social value. In addition, Drucker (1986) asserts that rather than focusing on efficiency, a more plausible explanation for buyouts is that executives of buyout firms have a comparative advantage at transferring wealth from stakeholders to shareholders by squeezing other beneficiaries of corporate wealth in situations where incumbent managers are unable or reluctant to do so. Moreover, these authors contend that gains in buyouts come not from efficiency, but from the exploitation of financial market misevaluations, and the use of tax benefits. In light of such criticism, Jacobs (1991), Pham and Hill (1995) warn that the agency prediction that buyouts increase efficiency should be taken with caution, as expectations do not always match outcome.

UK, European politicians, and trade unions have joined in the criticism of private equity and P-T-P buyouts. Franz Müntefering, Chairperson of Germany's ruling Social Democratic Party compared private equity executives to "swarms of locusts that fall on companies, devour all they can, and then move on." The trade unions argue that any value created by buyouts come not from operational efficiency created by new management teams after a buyout, but from asset stripping target companies and laying off large numbers of employees (Trade Union Congress, 2007). This resulted in Brendan Barber, General Secretary of the Trade Union Congress (TUC) accusing private equity executives of being "amoral asset strippers" and "casino capitalists" enjoying huge personal windfalls from deals as they gamble with other people's futures. Similarly, other opponents of buyouts argue that private equity corporate restructuring is damaging to economies, and the morale and productivity of organisations (Drucker, 1986, 1988; General Municipal Boilermakers and Allied Trade Union; 2007; International Union of Food, 2007; PES, 2009).

A number of leading financial experts have also queried the role of buyouts on the economy, and caution that the level of debt being taken on by private equity firms to finance their buyout deals could lead to financial instability (HCSC, 2007; FSA; 2007; TUC; Gregory, 2013). Private equity firms and the BVCA reject these concerns. They argue instead that companies owned by its members, out perform PLCs in term of efficiency, and that the performance of private equity backed companies "significantly strengthens the UK economy". However, the BVCA has yet to provide data to allow independent analysis of its claims. Lack of buyout data creates difficulties in addressing these competing arguments, particularly in the UK context.

In addition to not providing data to allow independent analysis P-T-P buyout efficiency, there is an absence of an agreed analytical framework to provide a definition of the type of efficiency to be measured in buyout studies, and the variables to be included. Almost every study commissioned by the BVCA fails to state the type of efficiency being measured, and measures efficiency at the fund, rather than at the individual company or plant level, and are based on variables at times too obscure to actually measure firm efficiency. Moreover, BVCA sponsored studies consistently fail to distinguish between venture capital and buyouts. This is a critical omission, since broadly speaking, private equity refers to an investment in an asset that is not tradable on the public markets, such as the London Stock Exchange. The term private equity actually covers a range of types of company financing ranging from venture capital, where money is invested in typically small businesses which are starting up or expanding, through to large scale P-T-P buyouts of the type which currently attract much attention (TUC, 2007), and which are the subject of this study. To be sure, venture capital is not contentious, but P-T-P buyouts are. Despite all of these limitations, until recently, most buyout studies commissioned by the BVCA report that companies involved in buyouts and owned and operated by private equity firms outperform PLCs in terms of efficiency.

Most early studies on buyouts are based on US data, and employ accounting or event study techniques in the analysis of firm efficiency. The results from these studies suggest that companies involved in buyouts and owned by private equity firms outperform PLCs. However, as policy decisions regarding the optimal level of buyout activity hinges predominantly on its impact on economic efficiency (Harris et al. 2005), and because of doubts over the efficient market hypothesis (which asserts that changes in share prices following a buyout announcement reflects changes in future real firm performance or economic efficiency), these suggest that accountancy and event studies may not be perfectly correlated with real firm performance (Shliefer, 2001). As these techniques measure the profitability of the company, and the movement in their share prices respectively, they are proxies for rather than measures of firm technical efficiency, and are no longer used in efficiency studies.

Lichtenberg and Sigel (1987) suggested that total factor productivity techniques (TFP) and plant level data is more appropriate for measuring technical efficiency. TFP studies, which have examined buyout efficiency and the duration of their gains, are inconsistent. Lichtenberg and Sigel (1987) report that buyout efficiency in US manufacturing plants last for up to seven years after buyouts. Opler (1992) find efficiency gains in US buyouts one year before the buyout, and report they last up to two years after. Benfratello (2002) finds that companies in the Italian pasta industry experienced increases in technical efficiency lasting up to six years following acquisition. Because TFP contains a one-sided error term and attributes all efficiency to management control, when it is not, this technique is no longer used to measure technical efficiency (Murillo-Zamorano, 2004).

In other buyout studies, practitioners prefer to focus on absolute returns in terms of multiples of invested capital. The disadvantages of these techniques are that the length of the 
holding period is not taken into account (Kreuter et al. (2005). To circumnavigate this problem, other studies measure buyout performance as the released gross IRR (Kreter et al. 2005). This allows differentiating as to whether buyouts with long holding periods justify the longer capital commitment with any corresponding higher appreciation in value (Kreuter et al. 2005). Other discussion points include general partner related factors, such as experience, industry focus, the ability to generate deals, proactively, acquisition process, such as the level of seller sophistication, or the determination of the appropriate level of management equity ownership (Kreuter et al. 2005). Not only do the results of such studies provide contradictory opinions among industry experts with respect to buyout performance, such studies and the variables used in them are unable to provide any meaningful insights into the technically efficiency of companies involved in P-T-P buyouts.

There are different ways of measuring efficiency in buyouts. However, the term 'firm efficiency' can be subjective, and when used, it is imperative that it is stated precisely what measure of firm performance is being discussed. Farrell (1957) stated that if the theoretical arguments as to the relative efficiency of different economic units are to be subjected to empirical testing, it is essential to be able to make some actual measurement of efficiency. Farrell (1957) developed a technique capable of measuring individual economic units (DMU). This technique was later termed data envelopment analysis (DEA) by Charnes et al., (1978). DEA is a non-parametric frontier technique, which uses data from observed companies to construct an efficiency frontier against which all other companies in the dataset are measured.

An advantage of using DEA is that the technique does not require an explicit a priori determination of a production function, and efficiency is measured relative to the highest observed performance rather than against some average (Cook et al., 1991, Ruggiero, 2007). DEA is capable of being used with any input-output measurement, and the source of efficiency can be analysed and quantified for every evaluated unit. Moreover, the technique is useful in uncovering relationships that remain hidden when other methods are used (Cook et al., 1991, Ruggiero, 2007). One drawback of DEA, is that the technique attributes all deviations from the frontier to inefficiency. A frontier estimated by DEA is therefore likely to be sensitive to measurement errors or other noise in the data (Odeck, 2007). However, despite its limitations, DEA provides new ways of obtaining empirical estimates of the external relationship, such as the production function, or the efficient production possibility surfaces that are a cornerstone of modern economics (Charnes et al., 1978).

Researchers in a number of fields have recognised the effectiveness of DEA for modeling operational processes, and its empirical orientation and absence of a-priory assumptions (Cook et al., Murillo-Zamoro, 2004, Coelli et al., 2005; Odeck, 2007) have resulted in the technique being used in a number of studies to evaluate firm technical efficiency in both the non-profit and for profit, and regulated and unregulated sectors (Cooket al., 1991, Murillo-Zamorano, 2004). In the USA and other countries, it is common for efficiency in P-T-P buyouts and other M\&A deals to be measured using frontier techniques. However, in the UK, the BVCA has used every measure in its possession to avoid having P-T-P buyout deals undertaken by its members being subjected to analysis using frontier techniques.

Pressure from UK and European governments and trade unions have force the BVCA and the researchers it sponsors to carry out more robust buyout studies. Alperpvych et al (2013) use a Malmquist DEA technique and UK buyout data to investigate the impact of vendor sources and private equity investors' experience on post buyout efficiency. The authors find that divisional buyouts have higher efficiency improvements than private and secondary buyouts. Multivariate analysis shows a positive and significant effect of private equity experience on post buyout efficiency, meaning that improvements in efficiency takes place only in the first two years after buyouts. These two results for UK buyouts are highly significant as they are the first to provide direct empirical evidence to refute the superior efficiency claims of the BVCA. Indeed, a 2013 report sponsored by the $\mathrm{BVCA}^{1}$ finds there is a consistent pattern of private equity backed buyouts with higher growth rates than non-private equity backed companies for the first four years of a buyout, however, after this period, efficiency in non-private equity backed companies, in other words, PLCs, is greater than that of companies involved in P-T-P buyouts.

The inconsistencies in the results of buyout studies are consistent with Rappaport's (1990) alternative buyout theory. This states that as managers of PLCs have adapted financial and operational techniques from companies owned and operated by private equity firms, such as shedding underperforming divisions, selling assets not essential to operations, repurchasing stock, increase leverage, close uneconomic plants and offices, and outsource much of their production processes, including materials and labour in response to changes in the competitive and financial environment, no efficiency gains are expected from P-T-P ownership changes. However, there have been difficulties in empirically testing these starkly differing theories in UK P-T-P buyouts.

While the insights provided by the BVCA and Alperpvych (2013) start to shed a little clearer light on buyout activities, these studies still tend to lump different types of private equity investment together treating them all the same when they are not (Wood et al. 2013, in the Financial Times). PLCs have objectives and constraints (e.g., fiscal balance and universal services, uniform price requirements, but at the same time, a soft budget constraint) different from those of private companies (Fried et al. 2008). Therefore, in order to level the playing field, the only common ground on which to compare the performance of PLCs, is on the basis of their technical efficiency (Fried et al. 2008). When discussing the

1 BVCA (2013): The growth Initiative - CEO Insights. 
economic performance of producers, it is common to describe them as being more or less efficient or more or less productive.

The productivity of producers means the ratio of their inputs to their outputs. This ratio can be calculated if the producer uses a single input to produce a single output (Farrell, 1957). In the more likely event that producers use several inputs to produce several outputs, the outputs must be aggregates in some economically sensible manner, as must the inputs so that productivity remains the ratio of two scalars (Fried et al. 2008). Productivity growth them becomes the difference between output growth and input growth. Variations in productivity either across producers or through time, is thus a residual. In principal therefore, the residual can be attributed to differences in production technology, differences in the scale of operations, differences in operating efficiency, and differences in producer operating environments (Farrell, 1957, Fried et al. 2008).

The controversial nature of buyouts, and government concerns over the lack of knowledge of the current and future impact of these transactions on the UK economy and employees, mean that more studies are beginning to focus more intensely on P-T-P buyout efficiency rather than on their profitability. This study contributes to the emerging literature on private equity buyouts by using a unique P-T-P buyout dataset to focus exclusively on P-T-P buyouts, the most controversial part of these transactions. This is necessary in order to contribute to a better understanding of buyouts to aide future policy makers and researchers to better understand the impact of these transactions on organisations, workers and ultimately, the economy. There is currently a dearth of information in this area.

This study uses DEA and plant level buyout data for 355 companies operating in the UK manufacturing industry during the period $1996-2007$, to investigate the technical efficiency of companies involved in UK P-T-P buyouts. The data used for this study differs from other studies in that the study is predominantly based on plant level data collected from the UK ONS, and relates specifically to UK P-T-P buyouts.

\section{Methods and Data}

\subsection{Data}

P-T-P buyout data for this study is obtained from two sources. The first is the Centre for Management Buyout Research at Imperial College London (CMBOR). The second is the UK Office for National Statistics (ONS) Annual Respondent Database (ARD).

The private equity industry works closely with the CMBOR and provides it with deal level information annually. Most of the information provided to the CMBOR by the private equity industry is on the type of buyout, date of the buyout, date buyout exits, name and address of the buyout, and the purchase price (table 1). No data on input prices are provided, nor does the CMBOR provide any plant level or reporting unit level data. In order to obtain such buyout data, an alternative data source is required.

Table 1. CMBOR Variables

\begin{tabular}{|c|c|c|}
\hline Name of Buyout & Type of Buyout & Buyout Source \\
\hline Address of Buyout & County & Region \\
\hline Month of Buyout & Year of Buyout & Buyout Activity \\
\hline Value of Buyout & Turnover & Activity Description \\
\hline Type of Buyout Exit & Year Buyout Exit & Month Buyout Exit \\
\hline
\end{tabular}

Table 1 shows the variables obtained from the CMBOR and used in this study. The list of variables provided by the CMBOR is more extensive than below. However, only these were selected for use in the ONS data match.

For the first stage of the data collection process, data for the population of 355 P-T-P buyouts for the period 1990 to 2009 is obtained from the CMBOR. The CMBOR was formed at the University of Nottingham in 1986, and moved to Imperial College London in 2011. The CMBOR is supported by private equity Equistone Partners Europe (formerly Barclays Private Equity) and Ernst \& Young. The CMBOR is the depository for UK and European private equity data. The primary source of information in the CMBOR files is a biannual survey of all private equity and debt providers in the UK and European buyout market. Other data sources include press releases, company reports and stock exchange circulars (CMBOR).

From the CMBOR buyout dataset, 62 companies are deleted because the data relates to periods before 1997, or after 2007.This leaves a sample of 293 UK P-T-P buyouts for the period 1997-2007. As the focus of this study is on P-T-P buyouts in the UK manufacturing industry, companies in the finance, insurance, agriculture, business services, wholesale distribution, computer services, media, real estate, medical health care, computer software, transportation, and communication industries are dropped from the CMBOR dataset, leaving a buyout dataset of 133 P-T-P buyouts. As the CMBOR reports that it does not hold input data for buyouts, this data has to be obtained from an alternative source.

Table 2. Industries Targeted by Buyout Firms.

\begin{tabular}{|c|c|c|}
\hline $\begin{array}{c}\text { Chemicals } \\
\text { manufacturing }\end{array}$ & Construction & Electrical engineering \\
\hline Food manufacturing & $\begin{array}{c}\text { Leather/footwear } \\
\text { m-m }\end{array}$ & $\begin{array}{c}\text { Mechanical instrument } \\
\text { eng }\end{array}$ \\
\hline Medical/pharmaceutical & Metal goods Eng. & Other manufacturing \\
\hline Paper manufacturing & Textiles & Timber/furniture \\
\hline Agriculture/fish & Media & Medical health care \\
\hline Wholesale distribution & $\begin{array}{c}\text { Banking/finance/ } \\
\text { insurance }\end{array}$ & $\begin{array}{c}\text { Computer software } \\
\text { Hotel/catering/leisure }\end{array}$ \\
\hline $\begin{array}{c}\text { Business } \\
\text { Rervices/leasing }\end{array}$ & Retail distribution & Biotechnology \\
\hline Computer services & & \\
\hline
\end{tabular}


In order to examine whether companies involved in UK P-T-P buyouts operate more efficiently than companies owned by PLCs, a matching dataset of PLCs is constructed by obtaining data for 473 manufacturing companies listed on the London Stock Exchange from Thompson Reuter's banker financial database. PLCs in the matching sample must be in the same industry as companies in the buyout dataset matched on four digits SIC code, and must not have been involved in a buyout during the period of study.

Data for the second part of the data collection process is obtained from the ONS ARD. The ONS is the executive office of the UK Statistics Authority, a non-ministerial department, which reports directly to the UK Parliament. The list of 133 P-T-P buyouts containing the names, address, and postcodes obtained from the CMBOR, and the PLC list is sent to the ONS for matching against its Inter Department Business Register (IDBR) for comparable records. The IDBR is the sampling frame for surveys of businesses carried out by the ONS and by other government departments. It is also a key data source for analysis of business activity.

The dataset of 133 P-T-P buyouts obtained from the CMBOR and the matching PLC dataset is sent to the ONS for matching with the IDBR. The purpose of the IDBR matching process is to obtain a unique ONS enterprise reference number for as many of the companies in the CMBOR and PLC sample as possible. No research work can be carried out on any ONS database without first obtaining an enterprise reference number for each company. An enterprise reference number allows an individual company to be followed through various time periods.

For the CMBOR dataset, the ONS IDBR returns 192 define enterprise reference matches, 922 multi-matches, and 46 definite no matches. Because sample size is always a concern for econometric work, especially in this study, which already suffers from a small buyout dataset, the IDBR multi-match folder is re-examined to see if it is possible to increase the size of the buyout dataset. This cleaning process provides an additional 55 definite enterprise matches, creating a total buyout dataset of 247 definite enterprise matches. The PLC dataset undergoes the same ONS probability matching process as the buyout dataset. This produces 295 PLC definite IDBR matches.

Table 3. Source of ONS and CMBOR Research Variables

\begin{tabular}{|c|c|c|}
\hline CMBOR & \multicolumn{2}{|c|}{ ONS } \\
\hline & IDBR & ARD \\
\hline Ownership & & Turnover \\
Date of Buyout & & Capital \\
Exit Date & & Labour \\
Buyout Type & Enterprise Reference & Materials \\
Exit Type & Number & Region \\
Sector & & SIC code \\
Region & & Year \\
& & \\
\hline
\end{tabular}

Table 3 shows the source and variables used in the analysis below. The CMBOR source provides the name of the buyout. This is used to create the ownership variable. The date of the buyout and exit date is used to identify the year the buyout starts and end. Buyout type is used to create a dummy variable for Buyout. Region is used to create a dummy variable for location, and buyout type is used to create a dummy variable for buyout. The ARD provides the output variables turnover, and input variables of capital, labour, and materials, variables used in the production frontier.

\subsection{Research Sample}

The buyout and PLC dataset obtained from the IDBR matching process is used to search the ONS ARD to obtain annual input and output data for each reference number. Each year in the buyout and PLC dataset is searched against the corresponding year in the ARD database. The ARD contains over 500 different variables. The variables of interest for this study are turnover, materials, capital, and employment. Companies with two or less years' data, and companies with missing data for turnover, materials, capital, and employment, and companies with zero balances are dropped. All companies in the sample are from industry 3 digits SIC code.

This cleaning process provides the final buyout and PLC research sample. For the buyout dataset, there are 65 enterprises, which own 103 sub-enterprise level units (reporting units). This provides a total of 704 observations. For the PLC dataset, there are 251 enterprises, which own 367 sub-enterprises (reporting units). This provides a total of 2377 observations. Combining the buyout and PLC datasets produces a total of 316 enterprises, 470 reporting units, and 3081 observations. This is combined to make the final unbalanced panel research dataset. The unbalanced nature of the panel from the ARD is useful for there is considerable entry and exit over a long period (Harris et al. 2005). One other advantage of having an unbalanced panel is that there are more chances of small as well as large companies being included in the sample.

\subsection{Variables}

The variables for the first stage of the DEA procedure are specified and described in the thesis dissertation of Miller (2014). Private Equity Buyouts and Firm Efficiency: Evidence from UK Public to Private Transactions. The second stage variables are:

TURNOVER - is calculated as the natural logarithm of real annual turnover. It is calculated at the reporting unit level by adding to the value of sales of goods produced, goods purchased and resold without further processing, work done and industrial services rendered and non-industrial services rendered. Turnover is also used to control for firm size in the matching PLC dataset.

CAPITAL - is calculated as the natural logarithm of capital stock. ${ }^{2}$ It is constructed at the reporting unit level by

2 When constructing capital stock for this study, capital stock with negative values or zero are dropped in accordance with the literature. 
the ONS using the Perpetual Inventory Method (PIM). ${ }^{3}$ In summary, the PIM depreciates the previous year's capital stock and then adds on the current investment, this process continues for each year of the series. ${ }^{4}$ The MAUS team that constructs the capital stock dataset uses the following depreciation rates set out by ONS: Plant \& Machinery $6 \%$, Buildings $2 \%$, and Vehicles $20 \%$. However, alternatives such as those based on BEA estimates include: Plant \& Machinery $13 \%$, Buildings $2.5 \%$. Vehicles $25 \%{ }^{5}$ Most research on efficiency is based on capital stock calculated using the PIM. For instance Hulten (1990), Lichtenberg and Sigel (1987, 1990), OECD (2001), Benfretello (2002), Amess (2003), Coelli et al (2005), Harris et al (2005), and the ONS calculate capital stock using the PIM technique. ${ }^{6}$

An evolving stream of literature suggests that capital services, which is a flow variable, better reflect the input of capital into production, and thus are more suitable for analysing efficiency than the wealth estimates of capital stock (ONS, 2006). ${ }^{7}$ An attempt to use capital services in this study was made. However, after extensive discussions with the ONS, it became clear that "capital services" could not be used as the measure of capital stock, as there are serious methodological problems with the ONS capital service datasets which have caused the ONS to suspend their use.

Other problems with constructing the capital stock variable include having to deal with a large number of negative capital stock values, some of which came about because the ONS only calculated capital stock values up to 2005. This was overcome by manually calculating a capital stock value for as many missing values as possible by using historical data from the ONS capital stock database. This still left a lot of missing capital stock values, which it was not possible to calculate capital stock values for.

$\boldsymbol{L A B O U R}$ - is calculated as the natural logarithm of total employment costs paid for labour during the year to employees. This includes all overtime payments, bonuses, commission, payments in kind, benefits in kind, holiday pay, employers' national insurance contributions, payments into pension funds by employers and redundancy payments, less any amounts reimbursed for this purpose from government sources. No deduction is made for income tax or employees' national insurance contributions etc, payment to working proprietors, travelling expenses, lodgings allowances, etc., are excluded.

In efficiency studies, labour is often measured in different ways. Lichtenberg and Sigel (1990) measured labour as the equivalent man-hours, calculated as production worker man-hours times the ratio of total wages and salaries to production workers. Amess (2003) measured it as the number of employees, and Benfrattello (2002) as deflated 3 For a detailed discussion on how the ONS capital stock is constructed,
see Martin (2002) and Gilhooly, (2008).

7 Gilhooly, (2008) Estimating capital stock at the firm level value added labour. However, the ONS ${ }^{8}$ argues that productivity measures based on hours worked have conceptual advantages over head count efficiency measures which are based solely on the number of workers or jobs rather than the time people actually work. According to the ONS, data on hours worked give a better indication of the actual volume of labour input because a measure of hours worked allows accounting for differences in working patterns. Unfortunately, the ARD holds no data on hours worked. Harris et al (2005) used real intermediate inputs as their measure of labour input. This study follows Harris et al (2005) in the use of real intermediate inputs as the measure of labour input.

MATERIALS - is calculated as the natural logarithm of the cost of raw materials and components used in the production processes. The goods made from these materials are sold to generate turnover. Because of the different types of products made by the UK manufacturing industry, no single definition of materials is available. Following Harris et al., (2005) material is defined as real intermediate inputs.

OWNERSHIP - is a dummy variable representing legal ownership of a company, i.e., public or private. It is constructed using data from the CMBOR and the LSE. PLCs are coded ( 0$)$ and private equity owned companies are coded (1). Ownership is a key variable since the literature suggests that companies involved in buyouts should be more efficient following a buyout than companies that do not engage in buyouts. No researcher size bias is exercised in the selection of companies to be included in the datasets. The only determinant of firm size is that generated by the data itself in the process of it being cleaned. The only requirement to be included in the datasets is that there must be two or more years of observations per company, as during the first year of ownership change, it is almost impossible to determine whether changes are the result of PLC or private equity ownership (Benfretello, 2002).

OWNERSHIP - is a dummy variable representing legal ownership of a company, i.e., public or private. It is constructed using data from the CMBOR and the LSE. A list of the population of all companies involved in P-T-P LBOs and MBOs during the period 1997-2007 and their industries are obtained from the CMBOR. A similar sample of PLCs is obtained from the LSE, and these are matched against comparable information held on the ONS ARD to create matching samples using turnover and SIC92 codes. No researcher size bias is exercised in the selection of companies to be included in the datasets. The only determinant of firm size; is that generated by the data itself in the process of it being cleaned. The only requirement to be included in the datasets; is that there must be two or more years observations per company, as during the first year of ownership change, it is almost impossible to determine whether changes are the result of PLC or private equity ownership (Benfretello, 2002). PLCs are coded (0) and private equity owned companies are coded (1). Ownership is a key variable since the literature suggests that companies

8 ONS Productivity Handbook, chapter 5 - Input measures: Labour and Capital 
involved in buyouts should run more efficiency following a buyout than companies that do not engage in buyouts.

BUYOUT is a dummy variable representing the type of buyout, i.e., leverage buyout or management buyout. This data is provided by the CMBOR, and is a sample from the population of LBOs and MBO for the period 1997-2007. To be included as buyout in the CMBOR database, over 50 per cent of the issued shares of a public company must change ownership with either management or a private equity firm or both, jointly having a controlling stake upon deal completion. Only buyouts with two or more years' observations are included in this variable. Private equity firms determine what is constituted as a LBO and an MBO, and this study follows the determination provided in the data from the CMBOR. This variable is used to estimate whether the type of buyout affects the efficiency of companies.

Table 4. Variable definitions and their expected relationship with efficiency

\begin{tabular}{|c|c|c|}
\hline Variable Name & Expected Sign \\
\hline Turnover & Annual turnover & + \\
\hline Capital & Capital Stock & + \\
\hline $\begin{array}{c}\text { Materials } \\
\text { Purchased }\end{array}$ & The cost of raw materials & + \\
\hline $\begin{array}{c}\text { Total Labour } \\
\text { Costs }\end{array}$ & The cost paid for labour & + \\
\hline $\begin{array}{c}\text { Ownership } \\
\text { Change }\end{array}$ & $\begin{array}{c}\text { Dummy variable representing } \\
\text { ownership changes }\end{array}$ & $+/-$ \\
\hline Buyout & $\begin{array}{r}\text { Dummy Variable representing } \\
\text { type of buyout }\end{array}$ & \\
\hline
\end{tabular}

\subsection{Summary Statistics}

Tables 5 and 6 present summary statics for the variables in the buyout and PLC dataset respectively.

In order to avoid the outlier effects and standardise data, all the values are taken in their natural logarithmic forms. As can be seen in table 10 and 11 , all the (minimum and maximum) values of the variables are close to the mean and the standard deviations are relatively normal (less than 2.5 ) in all cases. By normalising the data, the abnormalities in time series are substantially minimised.

Table 5. Buyout Mean

\begin{tabular}{|c|c|c|c|c|c|}
\hline variable & Obs & Mean & Std Dev & Min & Max \\
\hline lturnover & 704 & 10.77 & 1.437 & 0 & 14.49 \\
\hline lrcapstk & 704 & 9.071 & 1.794 & 2.890 & 13.35 \\
\hline lmatpurch & 704 & 10.16 & 1.391 & 0 & 13.78 \\
\hline ltotlab & 704 & 9.451 & 1.096 & 2.772 & 13.10 \\
\hline
\end{tabular}

Table 6. LC Means

\begin{tabular}{|c|c|c|c|c|c|}
\hline variables & Obs & Mean & Std Dev & Min & Max \\
\hline lturnover & 2377 & 10.56 & 1.58 & 0 & 14.60 \\
\hline lmatpurch & 2377 & 8.476 & 2.25 & 0 & 13.04 \\
\hline lncapstk & 2377 & 9.92 & 1.53 & 1.099 & 15.09 \\
\hline ltotlab & 2377 & 9.171 & 1.290 & 4.080 & 13.40 \\
\hline
\end{tabular}

Tables 5 and 6 indicate some interesting points. Both the buyout and PLC variables show similar patterns in terms of turnover. In order to examine the differences and similarities between buyout and PLC companies' variables, t-tests are conducted for each variable. The results show there is little or no statistical difference between the means for ownership and private equity at the five per cent level. The result therefore suggests that the hypothesis that ownership changes do not increase firm technical efficiency cannot be rejected. The mean of the dependent variable for turnover in the buyout and PLC dataset is 10.77 and 10.56 respectively. This indicates that the process of matching by firm size is relatively robust.

The mean of the buyout variable for materials is 9.071 (table 5) and 8.476 for PLCs (table 6). For capital it is 10.16 for private equity and 9.917 for PLCs respectively, and for labour it is 9.451 for private equity and 9.171 for PLCs respectively. On average therefore, turnover is fractionally higher for private equity owned companies than for PLCs. Capital seems to have the largest impact on turnover in private equity and PLC owned companies, followed by labour and materials.

\subsection{Model Specification}

This study employs a two-stage DEA variable return scale input oriented approach to investigate technical efficiency in companies involved in P-T-P buyouts in the UK manufacturing industry during the period 1997-2007. In the first stage, three input variables, materials, ${ }^{9}$ capital, labour, and turnover as the output variable are used to estimate efficiency scores for each company in the sample.

DEA is used to compute an efficiency score for a firm as the fraction of actual inputs that is required for the firm to be located on the efficient frontier to produce the same level of outputs. Suppose there are $m$ inputs and $S$ outputs. Let the input and output data for decision-making unit $\boldsymbol{j}$ be: $X_{i j}, \ldots . . ., X_{2 j,-,}, X_{m j}$ and $y 1_{j}, y 2_{j}, \ldots, y s j$, respectively. The variable return to scale DEA model can be expressed with a real variable $\boldsymbol{\theta}$ (efficiency score) and a non-negative vector of variables $\lambda=\left(\lambda 1 \lambda 2 \ldots \lambda_{n}\right)^{T}$. This model is one first proposed by Banker et al. (1984) and is similar to a model adapted by Lin et al (2008). The DEA mode is specified as follows:

$$
\begin{aligned}
& \theta^{*}={ }_{\lambda}^{\min } \theta \\
& \text { s.t } \sum_{i=1}^{n} \lambda_{j} X_{i j} \leq \theta X_{i} 0, \quad \sum_{i=1}^{n} \lambda_{j} y_{r j} \geq y_{r}, 0 \\
& \lambda_{j} \geq 0, \quad \sum \lambda_{j}=1 \\
& i=1,2, \ldots, m, r=1,2, \ldots, s, \mathrm{j}=1,2, \ldots, \mathrm{n}
\end{aligned}
$$

9 The variables in the first stage of the DEA process are specified in Miller (2014). 
Under the DEA methodology, a firm with an efficiency score of $100 \%$ is located on the efficiency frontier in the sense that its inputs cannot be further reduced without decreasing its outputs (Lin et al. 2009). A firm with an efficiency score below $100 \%$ is relatively inefficient (Farrell, 1957, Banker et al. 1984, Lin et al. 2009).

In the second stage of the DEA analysis, the efficiency scores obtained from the first stage of the DEA analysis are used as the dependable, and ownership and ownership dummy variable are used as independent variables to address the research hypothesis, and to estimate the following DEA model:

$$
e_{i, t}=\alpha \sum_{k} \beta_{k} X_{k, i, t}+\sum_{k} \theta_{k} \text { OWNERSHIP }
$$

$$
+\sum_{M} \theta_{M} \text { OWNERSHIP CHANGE }+\sum Y E A R+{ }_{u, t, t},(2)
$$

where $\boldsymbol{e}_{i, t}$ is the efficiency score (obtained from the first stage of the DEA process) for firm $i$ in year ${ }_{t} \boldsymbol{X} . \boldsymbol{t}, \mathrm{X}_{\mathrm{k}, \mathrm{t}}$ represents efficiency variables discussed in the section for data and summary statistics. Since efficiency scores are truncated below from zero and above from unity, $u_{i, t}$ is an error term with double truncation. The prevalent method in the literature to find the determinants of efficiency gaps among DMUs; is by using Tobit regression analysis because the efficiency scores are censored at the maximum value of the efficiency scores. Tobit regression uses the efficiency scores as the dependent variable for the possible candidates of influential variables (Ji and Lee, 2010).

\section{Results}

Table 7. Result for Ownership Change

\begin{tabular}{|c|c|c|}
\hline & \multicolumn{2}{|c|}{ Model (1) } \\
\hline lefficiency & Coef. & $\mathrm{P}>\mathrm{Z}$ \\
\hline Change & -.1201 & 0.002 \\
\hline _cons & 2.916 & 0.000 \\
\hline sigma & .9089 & - \\
\hline
\end{tabular}

The coefficient for CHANGE in table (7) model (1) is negative and statistically significant at the five per cent level. The result indicates that companies owned by private equity firms following P-T-P buyouts do not operate more efficiently than the control sample. Indeed as this is negative, using this measure of efficiency we find that those companies that changed ownership (to become buy outs) are less efficient than they were before, the opposite story to the policy rhetoric. The hypothesis that P-T-P ownership changes lead to greater technical efficiency is therefore rejected at the five per cent level. This suggests that buyouts may not be long lived as suggested by Jensen (1989) and Lichtenberg and Siegel (1990).
Table 8. Result for Ownership

\begin{tabular}{|c|c|c|}
\hline & \multicolumn{2}{|c|}{ Model (2) } \\
\hline lefficiency & Coef. & $\mathrm{P}>\mathrm{z}$ \\
\hline Ownership & -.1790 & 0.022 \\
\hline _cons & 2.916 & 0.000 \\
\hline sigma & .9089 & - \\
\hline
\end{tabular}

The coefficient for OWNERSHIP in table (8) model (2) is negative and statistically significant at the five per cent level. The result indicates that companies owned by private equity firms (1) have a lower efficiency than firm s owned publically ( 0 ). This confirms the results of the first regression presenting evidence that using this frontier measure of efficiency shows that buy outs are less efficient, rather than more efficient.

\subsection{Discussion}

The result for CHANGE is consistent with Rappaport's (1990) hypothesis, which states that no efficiency gains are expected from companies involved in P-T-P ownership changes, because managers of PLCs have learned from private equity firms how to operate their companies more efficiently. The result is in line with McGuckin and Nguyen (1995) who find that ownership changes are associated with the transfer of plants with above average productivity, and Franks and Mayer (1996) who find no evidence of significant underperformance in UK companies prior to buyouts. Amess (2003) reports that companies involved in UK buyouts have higher efficiency two years before the buyout, and Leslie and Oyer (2008) find no evidence that buyout ownership changes lead to companies owned by private equity outperforming PLCs in operational efficiency. These results are consistent with Roosenboom et al (2006) who report that private equity firms typically target fundamentally strong businesses. More importantly, the results are consistent with evidence from the BVCA (2013), and Alperovych et al (2013), which show that companies involved in P-T-P buyouts and owned by private equity firms outperform PLCs in terms of technical efficiency only in the short run.

Our results may help to explain the secretive nature of private equity, and why, for so long, the BVCA has refused to release buyout data to enable proper and independent analysis of its member's buyout activities. If, in terms of technical efficiency, companies are not being operated more efficiently after buyouts than if they had remained PLCs, in fact less efficiently using this measure, then this raises questions over the real purpose of buyouts. It also raises questions over where and how private equity raises the substantial amounts it does to pay to its selected shareholders and private equity executives.

The emerging literature suggests that this is achieved through asset stripping companies, and substantial 
reductions in employee numbers. This is consistent with the historical and emerging literature, and anecdotal evidence which show that the majority of gains from P-T-P buyout transactions derive from selling off the assets of target companies; often by way of sale and leaseback, reducing staffing numbers, and enforcing massive changes to their terms and conditions of employment. More controversially, private equity owned companies are known to force staff onto zero hours contracts, which does not guarantee workers any work. Unfortunately the small and very specific dataset employed in this study does not allow us to test these hypotheses directly at this time (this is the subject of a forthcoming paper). However, given the fact that the BVCA's own empirical evidence show that buyouts are only more efficient in the short term, it is difficult to reject the trade union's charge of asset stripping and laying off large numbers of staff leveled against private equity firms.

If, as suggested in the emerging literature, the profitability of buyouts derives from laying off large numbers of employees and changes to their terms and conditions of employment, then it is not unreasonable to assume a link between this and difficulties in the UK economy. If employees are being put out of work, working reduced hours, experiencing wages freezes, being paid minimum wages, or working on zero hours contracts, then it is not too difficult to imagine this having a negative long term impact on the UK economy. It is common sense that for every pound companies take from their workers, it is one pound less those same workers have to spend buying the company's goods and services.

The result for CHANGE is inconsistent with Jensen (1988) and Jovanvic and Rousseau's $(2002,2004)$ suggestion that ownership changes shift resources to more efficient uses and better managers. The results are also different from Lichtenberg and Siegel (1987) who report that plants involved in ownership changes operate more efficiently after buyouts than a control sample, and Benfratello (2002) who reports that acquired companies in the Italian pasta industry have above average improvement in efficiency after buyouts. The findings confirm Harris et al (2005) who find that plants involved in UK MBO are less productive than comparable plants before the transfer of ownership, and experience substantial increases in efficiency after the buyout. One reason for these results may be that the companies in those studies focused on the profitability of buyouts rather than on their technical efficiency.

Interestingly, the result for OWNERSHIP is negative and statistically significant. Recall from earlier that one of the main advantages of DEA is its ability to uncover relationships that remains hidden when other techniques are used (Cook et al., 1991). This result suggests that for the sample used and period under investigation, companies owned and operated by PLCs are operate more efficient than companies owned and operated by private firms. As for the result for CHANGE above, this calls into question the motives of managers of PLCs who recommend that their companies engage in P-T-P buyout deals. There is some suggestion in the literature that managers of PLCs sell the secrets of their companies to private equity firms in exchange for a seat on the board of the newly privatised company following the buyout, where they are often able to earn far greater in salary than if their companies had remained a PLC (Drucker, 1986).

We also tested to see whether the type of buyout transaction, or the location of plans have any impact of the technical efficiency of companies (not reported). No evidence is found to support either of these theories.

\subsection{Conclusions}

This study uses buyout data consisting of a sample of PLCs involved in P-T-P buyouts from the CMBOR, and plant level data obtained from the ONS, and DEA to examine the hypothesis that companies involved in P-T-P buyouts operate more efficiently after a buyout than companies owned and operated by PLCs during the period 1997-2007. DEA allows researchers to examine the technical efficiency of companies rather than their profitability, or the movement in their share price as in previous studies. The technique also allows technical efficiency to be measured at the plant or reporting unit, rather than firm level.

Taking into account the result obtained from the use of the variables and technique described above, we are confident that companies involved in UK P-T-P buyouts do not operate more efficiently than a sample of companies owned and operated by PLCs. The early gains from buyouts do not appear to be long lived, however, because of the speed of change in company ownership after a buyout, we are unable to test the long and short run effects of these transactions. We are satisfied that bulk of the gains from P-T-P transactions derive from reductions in employee numbers, un-negotiated changes to employees terms and conditions of employment, the imposition of zero hours contracts on employees, and from the sale and leaseback of the assets of target companies. A correlation matrix reported in Miller (2014) shows that the biggest contributor to firm technical efficiency comes from the reductions in employment costs.

No evidence is found that the type of buyout, or the location of plants has any impact on the technical efficiency of companies in the sample.

Our results show that in terms of technical efficiency, there is little if anything to be gained by PLCs going private, possibly something to lose in terms of efficiency. There are no doubts that PLCs have learned and adapted techniques from private equity firms on how to operate their companies more efficiently, including reducing staffing numbers, outsourcing much of their operations. However, it is unclear to what extent they have adapted the more controversial strategies, such as engaging in the sale and leaseback of corporate assets, and the imposition of zero hours contracts on employees. Therefore, in view of the suggestion in the literature that the differentiation between private equity and PLCs has waned (Ghai et al. 2014), PLCs may wish to further analyse private equity's past performance and its 
fundamental underpinnings, particularly, the skills, brand, focus and other capabilities the industry brought to its deals (Ghai et al. 2014), and determine, whether as an industry, or singularly, PLCs can, or wishes to replicate these to build better value for its own stakeholders. If PLCs are unable to, or choose not to follow private equity's lead further, an understanding of how successful private equity firms built their track records and how they will maintain them (Ghia et al. 2014), will help to inform PLC executives about the future prospects of any private equity firm in which they choose to invest.

The results of this paper suggest that the policy rhetoric and the reality on efficient gains from buy-outs are not consistent using this new measure of efficiency. We suggest that future work could provide a critical look at the measures of efficiency and their usefulness. Here we have proposed and used a new measure based on DEA which we think is more robust than previous measures. We suggest that policy makers take a critical look at research suggesting that they have found efficiency gains, especially when proxies such as share price and profitability are used to measure efficiency.

\section{REFERENCES}

[1] Alperovych, Y. Amess, K. Wright, M (2013). Private Equity Firm Experience and Buyout Vendor Source: What is their Impact of Efficiency? Europena Journal of Operational Research, 228: 601-611.

[2] Amess, K, (2003). The Effect of Management Buyouts on Firm-Level Technical Inefficiency: Evidence from a Panel of UK Machinery and Equipment Manufacturers. Journal of Industrial Economics, 51 (1) :35-44.

[3] Banker, R. D, Charnes, A, Cooper, W.W (1984). Some Models for Estimating Technical and Scale Inefficiencies in Data Development Analysis. Management Science, 30: 1078-1092.

[4] Charnes, A, Cooper, W.W, Rhodes, E (1978). Measuring the Efficiency of Decision Making Units. European Journal of Opertional Research: 429-444.

[5] Coelli, T, J. Rao, R. O’Donnel, C. Battese, G (2005). An Introduction to Efficiency and Productivity Analysis, 2nd Ed. Springer Science and Business Media. New York USA.

[6] Cook, Wade D., et al. "A data envelopment approach to measuring efficiency: case analysis of highway maintenance patrols." The Journal of Socio-Economics 20.1 (1991): 83-103.

[7] Benfratello, L (2002). Beyond Profitability: Effects of Acquisitions on Technical Efficiency in the Italian Pastry Industry. Managerial and Decision Economics 23: 399 - 415.

[8] DeAngelo, L, E (1986). Accounting Numbers as Market Valuation Substitutes: A study of Management Buyouts of Public Stockholders. Accounting Review, 400-420.

[9] Drucker, P.F (1986). Corporate Takeovers. What is to be Done? National Affair 55 (82): 3-24).
[10] Drucker, P (1988). Management and the World's Work. Harvard Business Review: :65-76.

[11] Farrell, M, J (1957). The Management of Productive Efficiency. Journal of the Royal Society. Series A (General) 120 (3): 253-290.

[12] Financial Services Authority (2007). Private Equity: A discussion of Risk and Regulatory Engagement, Feedback on DP06/6 07/3.

[13] Franks, J, Mayer, C (1996). Hostile Takeovers and the Correction of Managerial Failure. Journal of Financial Economics 40: 163-181.

[14] Fried, H. O. Lovell, C. K. Schmidt, S. S (Eds.). (2008). The measurement of Productive Efficiency and Productivity Growth. Oxford University Press.

[15] Ghai, S. Kehoe, C. Pinkus, G (2014). Private Equity: Changing Perceptions and New Realities. McKinsey \& Company. Insights and Publications April, 2014.

[16] Green, S (1992). The Impact of Ownership and Capital Structure on Managerial Motivation and Strategy in Management Buy-Outs: A Cultural Analysis. Journal of Management Studies, 29 (4): 513-535.

[17] Gregory, D (2013). Private Equity and financial Stability. Bank of England Quarterly Bulletin 2013 Q1.

[18] Harris, R. Siegel D, S. Wright, M (2005). Assessing the Impact of Management Buyouts on Economic Efficiency: Plant-Level Evidence from the United Kingdom. Review of Economics and Statistics. 87 (1): 144-153.

[19] House of Commons Treasury Committee (2007). Private Equity: Response from the Government and the Financial Services Authority to the Committees' Tenth Report of Session 2006-07.

[20] International Union of Food (2007). A Workers' Guide to Private Equity Buyouts. Geneva.

[21] Jarrell, G. A. Brickley, J. A. Netter, J. M (1988). The market for corporate control: The empirical evidence since 1980. The Journal of Economic Perspectives, 49-68.

[22] Jarrell, G. A. Brickley, J. A. Netter, J. M (1988). The market for corporate control: The empirical evidence since 1980. The Journal of Economic Perspectives, 49-68.

[23] Jensen, M, C (1984). Takeovers: Folklore and Science. Harvard Business Review 62: 109-121.

[24] Jensen, M, C. Meckling, W, H (1976). Theory of the Firm: Managerial Behaviour, Agency Costs and Ownership Structure. Journal of Financial economy, 3 (4): 305-360.

[25] Jensen, M. C (1988). Takeovers: Their Causes and Consequences. Journal of Economic Prospective, 2 (1): 21-48.

[26] Jensen, M. C. Ruback, R. S (1983). The Market for Corporate Control: The Scientific Evidence. Journal of Financial economics, 11(1): 5-50.

[27] Ji, Y. B., \& Lee, C. (2010). Data envelopment analysis. The Stata Journal, 10(2), 267-280.

[28] Jovanovic, B., \& Rousseau, P. L. (2002). The Q-theory of mergers (No. w8740). National Bureau of Economic Research. 
[29] Kreuter, B. Gottschalg, O. Zollo, M (2005). Truths and Myths about Determinants of Buyout Performance. In Conference Proceedings of the Annual European Venture Capital Association Meeting.

[30] Law, W.A (1986). A Corporation is More than its Stock. Harvard Business Review, 64 (3): 80-83.

[31] Leslie, P, Oyer, P (2008). Managerial Incentives and Value Creation: Evidence From Private Equity. National Bureau of Economic research, 14331: 1-40.

[32] Lichtenberg, F. R., Siegel, D., Jorgenson, D., \& Mansfield, E. (1987). Productivity and changes in ownership of manufacturing plants. Brookings Papers on Economic Activity, 643-683.

[33] Lichtenberg, F. R, Siegel, D (1990). The Effects of Leverage Buyouts on productivity and Related Aspects of Firms Behaviour. Journal of Financial Economics, 27 (1): 165-194.

[34] Lin, C, Su, D (2008). Industrial Diversification, Partial Privatisation and Firm Evaluation: Evidence from Publicly Listed Firms in China. Journal of Corporate Finance, 14 (4): 405-417.

[35] Lin, C, Ma, Y, Su, D (2009). Corporate Governance and Firm Efficiency: Evidence from China Publicly Listed Firms. Managerial and Decision Economics, 30 (3): 193-209.

[36] Lowenstein, L (1986). No More Cozy Management Buyouts. Harvard Business Review 64: 147-156.

[37] Manne, H. G (1965). Mergers and the Market for Corporate Control, Journal of Political Economy, 73 (2): 110-120.

[38] McGuckin, R.H. Nguyen, S.V. (1995). On Productivity and Plant Ownership Change: New Evidence from the Longitudinal Research Database. Rand Journal of Economics, 26 (2): 257-276.

[39] Meade, J. E. (1968). Is" The New Industrial State" Inevitable?. The Economic Journal, 372-392.

[40] Miller, L. (2014). Private Equity Buyouts and Firm Efficiency. Evidence from UK Public to Privte Tranactions. PhD dissertation. Unversity of Greenwich, London. UK.

[41] Odeck, J (2007). Measuring Technical Efficiency and Productivity Growth: A Comparison of SF and DEA on Norwegian Grain Production Data. Applied Economics, 39: $2617-2630$.

[42] OECD (2001. Organisation for Economic Co-operation and Development. Measuring Productivity: Measurement of Aggregate and Industry-level Productivity Growth: OECD
Manual. Organisation for Economic Co-operation and Development, 2001.

[43] Opler, T. C. (1992). Operating performance in leveraged buyouts: Evidence from 1985-1989. Financial Management, $21(1)$.

[44] McGuckin, R.H. Nguyen, S.V. (1995). On Productivity and Plant Ownership Change: New Evidence from the Longitudinal Research Database. Rand Journal of Economics, 26 (2): 257-276.

[45] Murillo-Zamorano, L.R, (2004). Economic Efficiency and Frontier Techniques. Journal of Economic Surveys, 18 (1): 33-77.

[46] Opler, T. C. (1992). Operating performance in leveraged buyouts: Evidence from 1985-1989. Financial Management, 21 (1).

[47] PSE (2009). Hedge Funds and Private Equity. A Critical Analysis.

[48] Phan, P. H. Hill, C. W (1995). Organizational Restructuring and Economic Performance in Leveraged Buyouts: An Ex Post Study. Academy of Management Journal, 38 (3): 704-739.

[49] Rappaport, A (1990). The Staying Power of the Public Corporation. Harvard Business Review 68 (1): 96-104.

[50] Rennboog, L. Simons, T. Wright, M (2007). Why do Public Firms go Private in the UK? The Impact of Privatr Equity Investors, Realignment and Undervaluation. Journal of Corporate Finance 13 (4): 591 - 628.

[51] Ruggiero, J (2007). A Comparison of DEA and the Stochastic Frontier models Using Panel Data. International Transactions in Operational Research 14 (3): 259-266.

[52] Shleifer, A. Summers, L (1988). Breach of Trust in Hostile Takeovers. In A. Auerbach, ed: Corporate Takeovers, Causes and Consequences (University of Chicago press).

[53] Trade Union Congress (TUC) (2007). Private Equity -a Guide for Pension Fund Trustees.

[54] Wright, M. Burrors, A. Ball, R. Scholes, L. Burdett, M. Tune, L (2007). Management Buyouts 1986-2006. Past Achievements, Future Challenges. Centre for Management Buyout Research. 20th Anniversary Year.

[55] Wright, M. Amess, K. Weir, C. Girma, S (2009). Private Equity and Corporate Governance: Retrospect and Prospect. Corporate Governance; An International Review, 17 (3): 353-375. 